Article

\title{
Can the SDGs Provide a Basis for Supply Chain Decisions in the Construction Sector?
}

\author{
Erica Russell ${ }^{1,2, *}$, Jacquetta Lee ${ }^{1}$ and Roland Clift ${ }^{1}$ \\ 1 Centre for Environment and Sustainability, University of Surrey, Guildford GU2 7XH, UK; \\ j.lee@surrey.ac.uk (J.L.); r.clift@surrey.ac.uk (R.C.) \\ 2 Previously also Carillion plc, Carillion House, 84 Salop Street, Wolverhampton WV3 0SR, UK \\ * Correspondence: e.f.russell@surrey.ac.uk; Tel.: +44-07713-177-236
}

Received: 30 November 2017; Accepted: 21 February 2018; Published: 28 February 2018

\begin{abstract}
The Construction sector is characterised by complex supply networks delivering unique end products over short time scales. Sustainability has increased in importance but continues to be difficult to implement in this sector; thus, new approaches and practices are needed. This paper reports an empirical investigation into the value of the UN Sustainable Development Goals (SDGs), especially Sustainable Consumption and Production (SDG12), when used as a framework for action by organisations to drive change towards sustainability in global supply networks. Through inductive research, two different and contrasting approaches to improving the sustainability of supply networks have been revealed. One approach focuses on the "bottom up" ethical approach typified by the Forest Stewardship Council (FSC) certification of timber products, and the other on "top-down" regulations exemplified by the UK Modern Slavery Act. In an industry noted for complex supply networks and characterised by adversarial relationships, the findings suggest that, in the long term, promoting shared values aligned with transparent, third-party monitoring will be more effective than imposing standards through legislation and regulation in supporting sustainable consumption and production.
\end{abstract}

Keywords: SDGs; construction; supply networks; sustainability; FSC; modern slavery

\section{Introduction}

\subsection{Construction and a Sustainable Supply Network}

Activity in the construction sector globally is expected to rise by $70 \%$ to 15 Trillion USD by 2025 [1], linked to global economic development associated with rising middle classes, increasing populations and a move to greater urbanisation. The sector generates around $50 \%$ of the waste by volume in developed countries, while buildings account for $19 \%$ of the world's energy-related $\mathrm{CO}_{2}$ emissions. Construction is identified by the United Nations Environment Programme as a key area to address to mitigate climate change, a position echoed by the most recent IPCC Assessment Report [2,3].

In the UK, the construction industry has been dominated over the last 30 years by the development of a subcontracting culture, driven by "market forces" and leading to work allocated primarily through competitive tendering. The resulting construction networks have been characterised as "hollowed out conglomerates" [4]: "temporary multiple organisations", created to respond to bespoke client requirements requiring involvement of many value-adding organisations [5]. As a result, the sector forms a complex supply network including investors, developers, public bodies, architects/designers, contractors, manufacturers, raw materials suppliers and demolition experts (see Figure 1). Main contractors act as project managers for clients, drawing together all the skills, services and materials required to create a physical asset. It is their role to procure goods and services, albeit frequently to a pre-ordained plan, and they are increasingly reliant on subcontractors 
and suppliers; these purchases represent typically $75 \%$ of their turnover [6,7]. The resulting fragmentation has created a supply network in which relationships are highly competitive and frequently adversarial [8,9], leading to narrow profit margins for main contractors, a major cause of the recent demise of the company studied in this work (Carillion) [10]. Relationships between network actors remain primarily dyadic, i.e., between the client and main contractor or main contractor and Tier 1 supplier [11], and the structure provides a limited basis for the development of trust between network members or collaboration in a supply network that is rarely managed beyond the first tier [12-14].

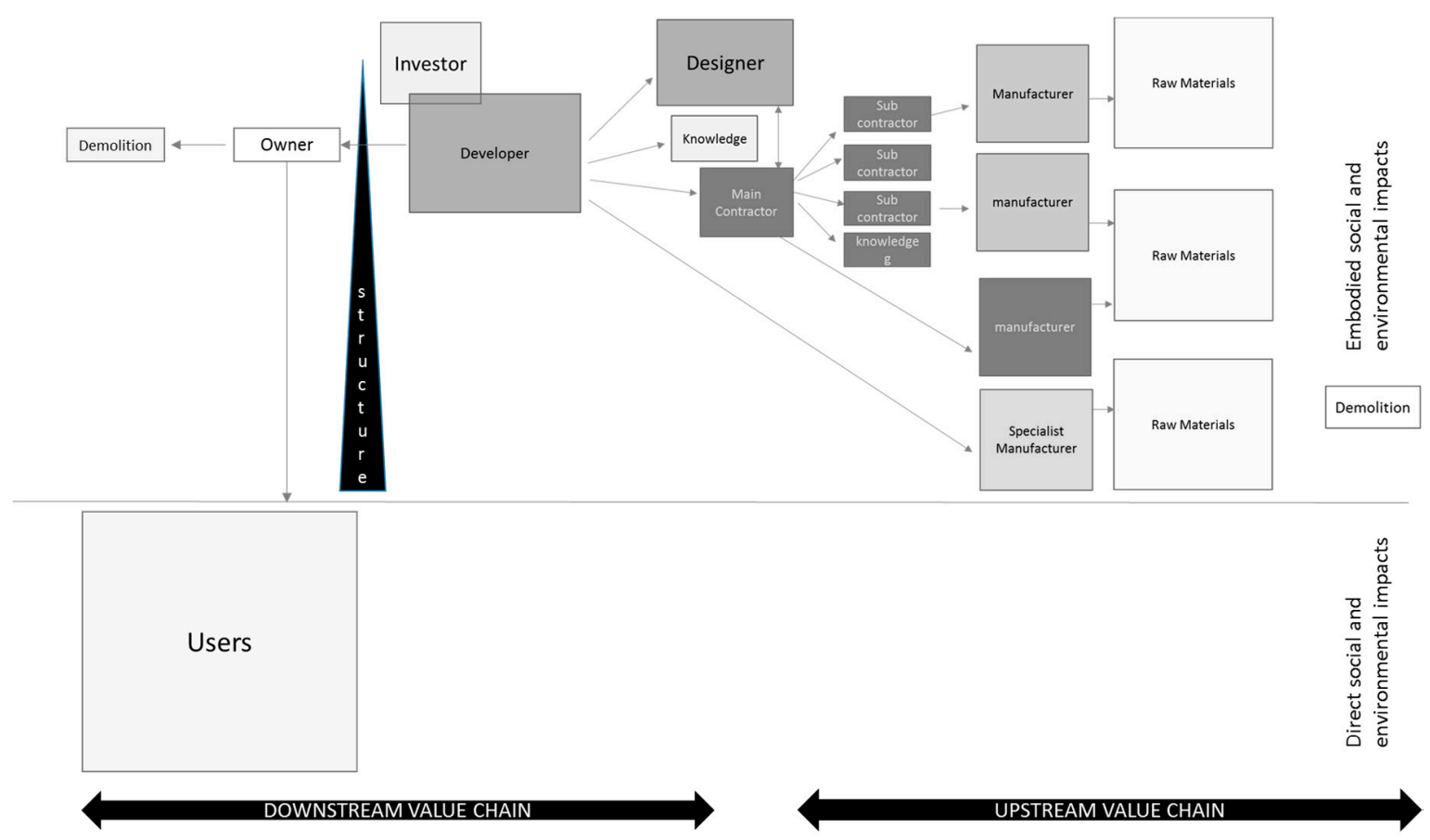

Figure 1. Simplified structure of a construction supply network [15]. Key: Increasing depth of shading in boxes demonstrates increased level of influence by Main Contractor. Increasing size of box indicates estimated increasing responsibility for impacts.

Despite these constraints, the UK Government has recognised that meeting sustainability targets in the construction sector depends on sustainable supply chain networks [16]. This creates a structural tension within the sector as the effective management of supply chains has become largely synonymous with collaborative forms of working [17]. Indeed, the sustainable supply chain management (SSCM) literature highlights collaboration and governance as powerful tools for facilitating sustainability initiatives [18]. For major construction contracts, changing business models have been shown to facilitate more collaborative working, including a move from "build" to "design and build" and "design, build, operate", the last an increasing feature of public-private partnerships. There has also been an associated increase in partnership working to win major contracts, e.g., involvement of multiple major contractors and manufacturers in the London Crossrail project or the formation of joint ventures (JV) such as CarillionAmey for MOD contracts. However, there is evidence that collaboration does not always result in beneficial outcomes $[19,20]$. It can also be difficult to achieve, as demonstrated in an industry-wide survey of 87 German firms by Brinkhoff and Thonemann which identified a $50 \%$ failure rate in collaborative supply chain relationships, the greatest issue being the difficulty of defining shared objectives [21].

There is a widespread view that sustainable consumption and production can only fully be achieved if the objectives of performance (economic, environmental and social) and principles of behaviour (quality) are shared, leading to common objectives, targets and requirements throughout the 
whole value network (e.g., [9,20,22,23]). This is not yet observed in the construction sector. For example, the industry annually procures over 380 million tonnes of resources [24] but inefficiencies within the network lead to $10-30 \%$ of waste materials being "unused product", including 800 ktons of shaped and sawn timber [25]. From a social perspective, the UK construction sector has been identified as a source of UK-based modern slave labour [26], with a significant proportion of the global $45.8 \mathrm{~m}$ people estimated to be subjected to modern slavery working within construction supply networks $[27,28]$. However, given the narrow profit margins noted above, the UK construction sector is typified by a focus on cost rather than value, with many companies seeking to transfer risk to others within the supply network. This acts as a strong inhibitor to undertaking initiatives directed at the environmental and social components of sustainability and heightens barriers to collaboration across the supply network.

Thus, although construction is an important sector for the promotion of sustainability in practice, it is characterised by serious structural problems. This paper reports on a heuristic study on the suitability of the Sustainable Development Goals (SDGs) in offering an effective collaborative framework to improve the social and environmental performance of the sector. In-depth interviews, surveys, and published sources have been examined, focusing on two different approaches implemented within one UK main contractor, Carillion plc (Wolverhampton, UK).

\subsection{Sustainable Development Goals}

The Sustainable Development Goals were adopted in 2015 [29] by the member states of the United Nations, in agreement with representatives of civil society and business, with the intention of guiding the global development agenda to 2030. They can be seen as an attempt to take the familiar representation of sustainability as "The art of living well within ecological limits" [30], complying with three sets of constraints-techno-economic efficiency, environmental compatibility and social equity [22] —and represent it in more tangible terms. In total, 17 different goals have been articulated, presumably divided in this way to aid understanding, acceptance and implementation. However, the SDGs are strongly interrelated, for example in ecological concerns such as the "nexus" of climate change, water availability and food supply, and in ethical concerns such as equity and justice. There are therefore questions, explored further in this paper, over the value of dividing the integrative concept of sustainability into so many apparently distinct goals.

Progress towards the SDGs to date has been slow [31]. The UN states that "Implementation and success ... will be led by countries, with all stakeholders ... expected to contribute to the ... agenda" [32]. In the UK, in 2017, a review by the Environmental Audit Committee of the House of Commons [33] concluded that " ... the Government seems more concerned with promoting the goals abroad, and has undertaken no substantive work to promote the Goals domestically or encourage businesses, the public sector and civil society to engage with the Goals and work towards meeting them". For commercial companies, the SDGs potentially represent a framework for articulating their social responsibilities and incorporating them in strategic planning. However, given the imprecise language and abstract level of many of the 169 targets, it is difficult to see how business could easily incorporate these into their practices. In addition, it is far from clear that the significance of the SDGs is sufficiently widely understood. For example, a recent survey [34] reported that more than $20 \%$ of European companies see "sustainability" as a source of competitive advantage but did not record to what extent they have truly grasped the concept as an imperative beyond commercial interest. The response most often reported is that companies are "developing products or services that will provide solutions in line with the Global Goals" [31], rather than attempting to embed the SDGs in planning and operations.

\subsection{Responsible Consumption and Production}

Notwithstanding the question over the value of subdividing sustainability goals into so many distinct categories, we focus in this paper on SDG12: Responsible Consumption and Production. This particular goal is selected because it is seen as one of the most central, relating closely to many of 
the other goals (many of which are subsidiary to this particular SDG), and yet is considered to be one of the five SDGs on which there has been least progress [30]. Furthermore, it requires attention to the whole supply network delivering products or services. Therefore, this goal provides a useful basis for exploring approaches to embed the SDGs into planning and practice.

Responsibility in supply chain management implies operating within ecological limits, as represented by the Planetary Boundaries defining the "safe operating space for humanity" [35,36], although there are serious difficulties in developing an operational approach to planning based on the Planetary Boundaries [37]. However, recognising that "sustainability" includes social equity, supply networks need to be more than just sequences of activities operating within ecological constraints; a supply network can be viewed as a set of relationships that convey benefits in both directions [23,38]. This view is exemplified by the fair trade movement, but has a more general significance in informing concepts of sustainable consumption [22]. Social responsibility in supply networks is a strong concern in the approaches examined here.

This paper reports an empirical investigation into approaches to network management in a UK-based multinational construction company, to explore how the SDGs-specifically No. 12: Responsible Consumption and Production (SDG12)—could be incorporated into planning and operations in a commercial company by contrasting "bottom-up" and "top-down" approaches to goal-setting. The results proved to be sufficiently informative to generate some conclusions with wider implications.

\section{Selection and Exploration of Approaches to Embedding the SDGs}

\subsection{Methodology}

This work forms part of a PhD programme, funded jointly by a public research agency (EPRSC) and what was until recently a leading private company (Carillion plc), directed at improving understanding of (un)sustainability in supply networks. The research has taken an inductive approach, aiming to develop a theory that is "grounded" in the data from which it has been derived $[39,40]$.

It was important that the research was carried out in a main contractor, Carillion plc, recognised for its sustainability credentials. The company published its first "environmental" report in 1997 and won Price Waterhouse-Cooper's "Building Public Trust" award for Sustainability reporting in three consecutive years. The company has clearly articulated corporate values encompassing economic, environmental and social issues_-"we care; we achieve together; we improve and we deliver" - and was already exploring how its existing approaches related to the UN Sustainable Development Goals. Its position as a main contractor made it the main node of the supply network. The company operated in the UK, Middle East and Canada, with an annual international procurement spend of 3.4 billion pounds sterling [41], working with over 8000 accredited first-tier suppliers and many thousands more in second and third tiers. Thus, involvement with Carillion offered an opportunity to examine how Responsible Consumption and Production can be incorporated into the operations of a commercial company.

During the initial phases of the PhD research in 2015, "purposeful sampling" [42] was undertaken to draw on the shared knowledge and experience of sustainable procurement within the company. Discussion with Carillion's Supply Chain Director and Sustainability Manager identified seven members of the supply chain team and two of the sustainability team likely to provide useful insights on interview. This provided a sample including both high and medium level decision makers, to provide a strategic overview of current procurement and sustainability within the company and the wider industry. Interviewees were also selected to offer a mix of job roles, from strategic to joint venture procurement, key project management, supplier accreditation and on-site sustainability monitoring (Table 1). 
Table 1. Team and Job Role of Orientation Interview Participants.

\begin{tabular}{clc}
\hline \multicolumn{1}{c}{ Team } & Role & Length of Interview \\
\hline Supply Chain & Supplier Accreditation and Monitoring & $1 \mathrm{~h}$ \\
\hline Supply Chain & Supplier Accreditation and Management & $1 \mathrm{~h}$ \\
\hline Supply Chain & $\begin{array}{l}\text { Managing Regional Strategy, supply chain } \\
\text { procurement-multiple projects, client liaison }\end{array}$ & $1 \mathrm{~h}$ \\
\hline Supply Chain & $\begin{array}{l}\text { Managing Regional Supply Chain Team-multiple } \\
\text { projects, client liaison }\end{array}$ & $1 \mathrm{~h}$ \\
\hline Supply Chain & $\begin{array}{l}\text { Managing Regional Supply Chain Team-multiple } \\
\text { projects, client liaison }\end{array}$ & $1 \mathrm{~h}$ \\
\hline Supply Chain & Managing Procurement-Joint Venture & $1.15 \mathrm{~h}$ \\
\hline Supply Chain & $\begin{array}{l}\text { Leading team for large public-sector project, delivery, } \\
\text { client liaison }\end{array}$ & $1 \mathrm{~h}$ \\
\hline Sustainability & Corporate Sustainability-policy, strategy and reporting & $45 \mathrm{~min}$ \\
\hline Sustainability & $\begin{array}{l}\text { Business Unit Sustainability Strategy-monitoring, } \\
\text { reporting, leading project sustainability }\end{array}$ & $1 \mathrm{~h}$ \\
\hline
\end{tabular}

At this initial stage of the research, the "orientation interviews" used a semi-structured format to prompt responses but to also allow the interviewer to explore themes or comments in more depth (see Appendix A for prompt questions). Open coding of the interview transcripts identified two sustainability issues where participants noted proactive, multi-tier engagement with the supply network: responsible sourcing of timber through Forest Stewardship Council (FSC) certification and Modern Slavery. Consideration of these two issues by the paper's authors confirmed that they represented contrasting approaches to supply network sustainability (see Table 2). They were therefore selected as suitable cases for further exploration.

Table 2. Comparison of Forest Stewardship Council (FSC) and Modern Slavery (MS) supply network approaches identified during "orientation interviews".

\begin{tabular}{lll}
\hline Status & FSC & Modern Slavery \\
\hline Lead & Optional & Mandatory \\
\hline Time & bottom-up & top-down \\
\hline Corporate Drivers for Action & $\begin{array}{l}\text { Initially NGO pressure and consumer } \\
\text { concern on product providers } 1\end{array}$ & $\begin{array}{l}\text { 2 years since implementation } \\
\text { of UK act. Process still } \\
\text { developing }\end{array}$ \\
\hline $\begin{array}{l}\text { Personal Drivers for } \\
\text { Chain team }\end{array}$ & $\begin{array}{l}\text { High decision makers with values } \\
\text { aligned to FSC social and } \\
\text { environmental aims }\end{array}$ & $\begin{array}{l}\text { Meeting legalisation, } \\
\text { alignment with general values }\end{array}$ \\
\hline Network Collaboration & $\begin{array}{l}\text { longer term collaboration has allowed } \\
\text { development of relationships and } \\
\text { trust within network }\end{array}$ & $\begin{array}{l}\text { short development time } \\
\text { resulting in collaboration } \\
\text { primarily with peers }\end{array}$ \\
\hline Implementation & FSC policy, Chain of Custody & MS Policy, and Audit \\
\hline
\end{tabular}

${ }^{1}$ EU timber import regulation introduced in 2010 [43].

To develop understanding of how the company approached FSC certification and Modern Slavery, multiple data collection methods were adopted to allow triangulation of results. Further interviews were added with individuals whose importance was highlighted during the semi-structured interviews: 
two supply chain team members responsible for procurement of timber with FSC certification. The researcher was also allowed to observe internal meetings on Modern Slavery by the Carillion Sustainable Procurement Steering Group. To understand the perspective of Carillion procurement teams on FSC certification and Modern Slavery, these issues were included in an on-line survey sent to all 94 supply chain team members and the sustainability manager. A response rate of $72 \%$ provided 68 completed surveys. The demographics of the respondents were $75 \%$ male, with $6.3 \%$ of respondents being aged $15-24,32.8 \%$ aged $25-44$ and $60.9 \%$ being aged $45-64$. Respondents were also classified by decision making level, verified by the Supply Chain Director. High Level decision makers accounted for $18.8 \%$ of respondents, medium level $57.8 \%$ and $23.4 \%$ at the limited decision-making level. Questions were rated by participants using the Likert scale to provide more nuanced answers and these were analysed using SPSS. Team members were also given the opportunity to comment. Transcribed interviews, meeting notes, other observations and materials were coded in MAXQDA software, building on the initial open coding and allowing the emergence of themes and concepts. In the final, selective coding phase [44] illustrative quotes were derived. Additionally, "company" information was supplemented and cross referenced with industry literature, Carillion annual sustainability reports and other materials available publicly online. Carillion staff provided feedback and identified errors and/or omissions. The resulting "bottom-up" and "top-down" cases were then analysed (Section 3) using the methodology for cross-case analysis proposed by Khan and Van Wynsberghe [45] for making deductions from a small number of cases.

\section{2. "Bottom-up" Goal Setting: Forest Stewardship Certification}

The Forest Stewardship Council (FSC) Chain of Custody represents an attempt to frame objectives, targets and requirements that can be shared throughout the supply network for forest products. The FSC originated in the early 1990s through discussions between the World Wildlife Fund (WWF, now Worldwide Fund for Nature) and several major UK DIY chains, concerned about the impact their procurement of wood was having on rainforests and the risks this entailed [46]. The group, WWF95+, wanted an industry-wide approach to ensure that the timber they purchased could be "guaranteed" as ethically sourced. This desire was compounded by the failure of governments at the Rio Earth Summit to reach an agreement to stop deforestation. From the outset, FSC took a non-governmental approach, harnessing commercial drivers to effect change. FSC has striven for, and increasingly achieved, a membership-based approach to forest management. It now provides all interested groups a voice at their membership forum and is overseen by a board elected by the membership. Decisions on forest management include indigenous people through local consultation. Local workers are prioritized for employment, which must include training in safety and use of equipment, and must be paid a "decent" salary [47]. Audits are carried out to ensure that the principles behind the approach are met. The social and environmental benefits and the associated reduction in risks resulting from this local, ethical approach to forest management are then propagated through the supply network, with the "Chain of Custody" assured by recording each step in the process. Evidence from WWF indicates that many smaller producers have benefited financially from FSC whilst larger scale producers have derived less advantage [48]. Since its inception in 1993, FSC has grown to be a significant market mechanism to promote responsible forest management, now covering 180 million hectares of forest in 112 countries.

By 1998, WWF95+ had grown to 86 participants including Tarmac (from which Carillion (Wolverhampton, UK) emerged in 1999). Tarmac was the first construction company to be engaged in the WWF95+ group and was seen by WWF as an important agent to bring benefits to both construction and forest industries. Carillion, driven primarily by corporate environmental values and reputational risk management, published a Sustainable Timber Policy, ratified by the Carillion board, to purchase only timber and wood-derived products with FSC Chain of Custody certification or, where this could not be achieved, to use sources that were independently verified as legal and sustainable. Requiring procurement teams to source only certified sustainable timber represents 
a major commitment, and it is clear from interview comments that this continued irrespective of client demand: "no client ever requested FSC apart from occasionally" (high-level decision maker). The principle was communicated to clients, sub-contractors and other suppliers.

Carillion accepted that, without a certified standard, it could not guarantee it was not colluding with or procuring timber from illegal logging operations; FSC provided a way for Carillion to ensure that its supply network did not contribute to illegal and destructive deforestation and thereby to avoid potential reputational risk. However, it was also made clear that Carillion's aim reached beyond its own network, "to promote demand and improve competitive pricing for FSC timber within the construction industry as a whole" [49]. Indeed, this was seen most recently in Oman, when Carillion's joinery workshop was the first in the country to have FSC Chain of Custody certification [41]. Carillion continued to support FSC and its incorporation into its procurement and operational processes. In 2013, Carillion updated its Timber Policy as part of a wider corporate 2020 sustainability strategy.

Operating the FSC "Chain of Custody" demanded additional commitment. This included guidance and training material for Carillion procurement and operations staff and ongoing, intensive engagement with suppliers and subcontractors bringing timber onto site as part of contract works packages. As noted by a high-level decision maker, "whilst it remains outside the industry norm you just have to continuously communicate it. People still don't really know what they are buying. They don't know how to maintain chain of custody". The company set up internal systems to manage the monthly reporting of timber usage and report this annually in its independently audited Annual Sustainability Report. Nevertheless, even after twenty years of commitment to the FSC Chain of Custody, Carillion continued to experience several major challenges in requesting FSC timber as its primary option and propagating this principle through the supply network. These included influencing or controlling sub-tiers in the supply network where there is a lack of contractual status, ensuring record keeping met Chain of Custody requirements and, linked to this, committing staff and management time to resolving reporting anomalies such as "they'd used more FSC timber on the job than the whole of the UK in a year" (high-level decision maker) [49].

Despite these concerns, this "bottom-up" ethical approach to timber management delivered some successes. By 2009, timber with no certification represented only $7.9 \%$ of Carillion's total purchases and continued to reduce, with annual fluctuations, to 5\% during 2015 [50,51]. Carillion was committed to $100 \%$ purchases of certified sustainable timber and wood by 2020 . Increased availability of FSC or a similar Chain of Custody organisation, the Programme for the Endorsement of Forest Certification (PEFC), has enabled more wholesalers and suppliers to offer Chain of Custody products. Increased internal monitoring and awareness supported and were supported by this change. Carillion continued to place an emphasis on the role of FSC in preventing deforestation [41]. For example, the 2017 Carillion supply chain team survey identified that $67.7 \%$ believed that the most important reason for the company supporting responsible sourcing of timber was its alignment with Carillion's environmental and social values, ensuring that forests remained "alive for future generations" [52]. Minimisation of reputational risk due to unethical sourcing was also identified as a major benefit of FSC Chain of Custody, rated as highly important or important by $65 \%$ of respondents. Whilst still facing challenges in procuring FSC timber, the company worked to identify and support improvement in its supply network, focusing on "temporary" wood products where there is less awareness of FSC materials amongst subcontractors. Carillion promoted FSC certification to its upstream suppliers, but engagement was more limited in the sector's downstream value chain: whilst certified timber does gain credits within building standards such as BREEAM, few clients directly specify FSC or other responsibly sourced timber materials. Furthermore, unlike companies supplying the consumer market, there is no direct communication between main contractors in the construction sector and the end users of the structures, most of whom will be unaware of timber sources. 


\subsection{Top-down Goal Setting: Modern Slavery}

The issue of forced labour, employed directly or more remotely through supply networks, has for some time been addressed through voluntary codes of conduct such as that promoted by the International Labour Organisation (ILO) or the UN Global Compact. However, the UK Government, in 2015, passed the Modern Slavery Act [53], requiring all UK companies to address the issue of modern slavery in their own businesses and their supply networks. Modern slavery is considered to be delineated by bonded labour, poor wages, working and living conditions, intimidation and violence or human trafficking. Companies with a turnover of more than $£ 36 \mathrm{~m}$ must demonstrate the action they are taking and publicly report this on an annual basis. The act affects all UK-based companies and is also generally accepted to apply to all non-UK based subsidiaries. In setting this legislation, the government has imposed values and specified the process by which all UK companies must engage with this issue, in marked contrast to the way FSC certification has developed more organically.

The UK Government initially suggested that there could be between 10,000 and 13,000 people enduring modern slavery in the UK [54]. The worldwide figure has been estimated at 45 million [27], with construction identified as a major area of concern because of its high reliance on flexible, temporary labour and highly diverse global supply networks.

Globally it is estimated that 7\% of the world's workforce is employed in the construction sector [27]. The complexity of labour issues in construction is compounded by the large number of different materials used (see Section 2.2), with up to 10,000 different component parts being required for the construction and use phase of buildings [55]. Companies primarily manage labour issues as part of their product supply networks but the high numbers of products and components, often originating from unknown global sources, makes it difficult to ensure transparency in employment practices. Even in relatively short supply networks, such as within the UK, mapping labour practices can become complex. Complexity can make the different forms of modern slavery, which are frequently informal and transient in nature, hard to detect and therefore persistent [56-58].

Carillion first used assessment tools in 1999 to review the environmental performance of suppliers. From this work, they identified that only $50 \%$ of suppliers broadly met requirements. As a result, Carillion began to address the social aspects of its suppliers' services and products by engaging with suppliers to promote sustainable sourcing of products and materials, "with high risk suppliers being encouraged to change practices rather than being delisted" [49]. The company made it clear that ensuring human rights was a key company principle and that they had "an ongoing commitment to improve the living and working conditions ... not just for direct employees but also for our subcontractor teams" [49]. The Modern Slavery Act 2015 went further, demanding greater transparency across the supply network, with clear evidence of company engagement. Along with many of its peers, Carillion included questions on their supplier registration system relating to human rights, asking for confirmation that companies had employment practices in line with the ILO or UN Global Compact on human rights, i.e., that they ensured fair wages and freedom of association, with no forced labour. They also asked companies if they engaged in responsible sourcing within their own supply networks.

A senior-level working group within Carillion reviewed existing company approaches and risks and, as a result, accepted that for many smaller suppliers, the Act and the concept of modern slavery represented a little-known issue. This was reiterated by the supply chain team with one member stating, of suppliers, "There is limited knowledge out there and even less on how it will be implemented" (medium-level decision maker). A large part of the company's efforts was therefore directed at engagement and awareness raising. At a company level this was achieved by direct communication with Tier 1 suppliers, changes to the supplier registration process, information and awareness raising via Carillion's own website and Carillion's own externally facing supply chain teams and operational staff. Questions on the internal supplier registration system were expanded to include the term "modern slavery" and, to support smaller companies, and in 2016 Carillion's Labour Standards Charter was developed [59] which suppliers could sign and adopt if they did not have their own processes in place. However, Carillion also identified that slavery was an industry-wide 
concern which, whilst highlighted by legislation, strongly resonated with the values of their peers and would benefit from collaborative efforts. In 2012, to meet gaps in sub-sector specific sustainability skills, Carillion, along with industry peers, helped create and co-fund an on-line skills platform, the Supply Chain Sustainability School (SCSS). By 2015, the free-to-use "school" had thousands of industry members. To overcome the knowledge gap on Modern Slavery, a group from the SCSS encouraged and facilitated main contractors, clients and major manufacturers to work collaboratively to create new slavery guidance directed specifically at the construction industry. Skills modules on Modern Slavery and the Act, along with video materials and written information, were developed and promoted by main contractors and clients to organisations in their supply networks [60]. However, progress of awareness across the network remains slow, with $21 \%$ of Carillion supply chain team identifying, in 2017, that most or many of the Tier 1 suppliers they worked with did not know about the Modern Slavery Act [52].

For companies operating in the UK, the Modern Slavery Act aligns with general societal norms and values and builds on existing legal requirements; and yet slavery can still occur. Detection becomes even more difficult when company operations or supply networks span countries or regions where different operating principles are accepted and where government engagement may be less developed. As a specific example, Carillion identified its highest risk area as its Middle East and North Africa (MENA) businesses, particularly in relation to worker welfare standards. Carillion had operated for more than 40 years in the Middle East, a region that has been experiencing an immense building boom. Organisations such as the Business and Human Rights Resource Centre have identified major human rights abuses in the region, such as migrant workers being subjected to high recruitment fees, non-payment of wages and restricted mobility. A separate Carillion-MENA Welfare Steering Group was therefore established.

In 2009, Carillion established a business in Qatar to provide construction, infrastructure and facilities management services; it grew to employ approximately 1100 people directly, with a further 6000 employed through subcontractors [6]. Carillion entered into a commitment that employees would be paid in accordance with Qatar Labour law but, in addition, that employees would also receive flights home, holiday pay, health insurance and accommodation and food. They set standards for accommodation that landlords had to meet prior to contracting, and required accommodation to be audited to ensure the standards continued to be met. Carillion put in place processes to ensure that employees have freedom of association, routes to express grievances and work to the same Health and Safety standards as in the UK, replicating the "Don't Walk By" culture used on all UK construction sites. However, in 2014, they were publicly accused of having subcontractor labour on site who had been forced to surrender their passports and were living in poor accommodation and receiving only a small part of the promised wages [61]. In response, Carillion implemented a similar approach for workers employed through sub-contractors. In one of the most contentious areas, that of recruitment, Carillion worked with "preferred suppliers" who had been reviewed for financial, ethical and professional conduct. It also carried out spot checks and terminated contracts with companies that charged excessive fees or had been unethical in their approach. A company like Carillion does not have direct control over its subcontractors; however, they are expected, as a minimum, to comply with Qatari labour laws. Carillion proactively reviewed and monitored the employment practices and accommodation of its suppliers and their subcontractors; only those that met Carillion's standards were included in the preferred supplier list. During 2016, the Carillion Board members visited two accommodation sites in the Middle-East as part of the audit process. When the Business and Human Rights Resource Centre approached the top 100 construction companies working in Qatar and UAE requesting feedback on their approach to worker's rights, Carillion was one of the first companies to respond but only 22 companies in total replied [62]. Qatar has seen an increased drive by global construction contractors to remove modern slavery from their supply networks but media reports, mainly fuelled by the reports of campaigning NGOs, continue to focus on poor worker conditions. In December 2016 Qatar abolished its "kafala" system of worker recruitment and, 
whilst Amnesty International notes "it leaves the same basic system intact", this does demonstrate that the state is responding to pressure and supporting change [63].

\section{Observations and Comparisons}

Cross-case comparison provides the opportunity to learn from different cases and to gather critical evidence to modify policy [45]. This type of comparison, considering general and distinctive characteristics between a small number of cases, has already been utilised to support policy recommendations on the role of supply chain collaboration in affordable housing development [64] and to examine sustainable supply chain management in the textile sector [65]. Using a case-oriented process, the FSC and Modern Slavery approaches outlined in Sections 2.2 and 2.3, were analysed to look for patterns of similarities and differences. The themes identified have been collated in Table 3 , illustrating the main benefits and challenges within each theme. The observations reveal how the SDGs align with the top-down and bottom-up approaches.

Table 3. Benefits and challenges associated with top-down and bottom-up approaches.

\begin{tabular}{|c|c|c|c|c|}
\hline Theme & & Modern Slavery (Top-Down Goal Setting) & & FSC (Bottom-Up Goal Setting) \\
\hline \multirow[t]{2}{*}{$\begin{array}{l}\text { Defining 'What } \\
\text { is right' }\end{array}$} & B & $\begin{array}{l}\text { Commitment by Government to a legal } \\
\text { 'solution' defines the 'ethical' position for the } \\
\text { supply network. }\end{array}$ & $\mathrm{C}$ & $\begin{array}{l}\text { Requires commitment, to buy FSC timber } \\
\text { and create market demand, which can be } \\
\text { difficult in a business-to-business sector. }\end{array}$ \\
\hline & & & B & $\begin{array}{l}\text { Negotiated' agreement across the supply } \\
\text { chain-engagement with personal and } \\
\text { corporate values }\end{array}$ \\
\hline \multirow[t]{2}{*}{ Collaboration } & $\mathrm{B}$ & $\begin{array}{l}\text { In the UK the legal requirement has created a } \\
\text { level playing field and engendered } \\
\text { collaboration between construction industry } \\
\text { organisations / companies. This has resulted in } \\
\text { shared costs. }\end{array}$ & B & $\begin{array}{l}\text { Demands collaboration along the supply } \\
\text { network. }\end{array}$ \\
\hline & & & $\mathrm{C}$ & $\begin{array}{l}\text { Supply network collaborators may have } \\
\text { different goals (i.e., improved living } \\
\text { conditions, reducing loss of rainforest, } \\
\text { minimising cost). }\end{array}$ \\
\hline \multirow{5}{*}{ Relationships } & $\mathrm{C}$ & $\begin{array}{l}\text { It is difficult to get beyond Tiers } 1 \& 2 \\
\text { especially in global networks; modern slavery } \\
\text { most likely to occur in tiers } 4,5 \text { and beyond. }\end{array}$ & B & $\begin{array}{l}\text { Considers social, environmental and } \\
\text { economic issues making it attractive for } \\
\text { local communities to engage and support. }\end{array}$ \\
\hline & $\mathrm{C}$ & Tentative relationships with NGOs & $\mathrm{B}$ & $\begin{array}{l}\text { Strong supportive engagement of NGOs } \\
\text { offering critical assessments and } \\
\text { validation. }\end{array}$ \\
\hline & & & $\mathrm{B}$ & $\begin{array}{l}\text { Positive benefits to downstream SMEs } \\
\text { engaged in process. }\end{array}$ \\
\hline & & & $\mathrm{B}$ & $\begin{array}{l}\text { Senior procurement staff are engaged } \\
\text { with downstream end suppliers (FSC) }\end{array}$ \\
\hline & & & $\mathrm{B}$ & $\begin{array}{l}\text { Reduces the likelihood of modern slavery } \\
\text { as it can remove exploitative drivers e.g., } \\
\text { illegal logging }\end{array}$ \\
\hline Control & $\mathrm{C}$ & $\begin{array}{l}\text { Modern slavery is driven by issues outside the } \\
\text { control of corporate organisations i.e., } \\
\text { inequalities, legal protection of vulnerable } \\
\text { workers in some countries }\end{array}$ & $\mathrm{B}$ & $\begin{array}{l}\text { Operates as a non-governmental process, } \\
\text { unrestricted by national borders. }\end{array}$ \\
\hline \multirow[t]{2}{*}{$\begin{array}{l}\text { Ability to } \\
\text { Deliver }\end{array}$} & $\mathrm{C}$ & $\begin{array}{l}\text { Demands for 'no slavery in the supply network' } \\
\text { are strained by time pressured delivery } \\
\text { requirements. }\end{array}$ & $\mathrm{C}$ & $\begin{array}{l}\text { Documenting Chain of Custody is critical } \\
\text { to maintain credibility but increases costs } \\
\text { and is complex to manage }\end{array}$ \\
\hline & $\mathrm{C}$ & $\begin{array}{l}\text { Modern slavery is frequently linked to 'illegal' } \\
\text { labour and exploitation-policies, charters and } \\
\text { audits struggle to reach lower Tiers }\end{array}$ & & \\
\hline Transparency & $\mathrm{C}$ & $\begin{array}{l}\text { Reporting by major companies but currently } \\
\text { weak driver across rest of supply chain }\end{array}$ & B & Detailed and transparent reporting \\
\hline
\end{tabular}
Key: B: Benefit to Contractor. C: Challenge to Contractor. 
Both FSC and Carillion plc have committed to support the SDGs [51,66]. Indeed, the FSC Chain of Custody approach provides a well-established collaborative supply network of the type identified by the UN as necessary to effect change. However, this work confirmed that those engaged in the FSC timber value chain support the SDG "Sustainable Consumption and Production"-indeed, the Forest Stewardship Council have identified it as one of the goals to which they aspire-but showed that they do not see it as a primary focus. FSC believes that another goal, SDG 15-"Life on Land"-is most relevant to their work, specifically target 15.2 "progress towards sustainable forest management". The Council has furthermore identified that, for those within the supply network, FSC accreditation provides a tool that supports 11 SDG goals and 35 targets (Appendix B, Table A1) [66]. Carillion had also reviewed the SDGs and undertook a major materiality survey, asking staff, clients and other stakeholders to identify the goals they felt Carillion could effectively support. Stakeholders identified five goals, all of which focused on social equality or business innovation, but of these only Goals 5 (Gender Equality) and 8 (Decent Work and Affordable Growth) aligned with FSC's goal selection. In 2017, Carillion published its Annual Sustainability Report noting support for nine SDGs. The additional goals recognized the importance of impacts within its supply network (SDG12) and on environmental issues (especially SDG 15: Life on Land) and also SDG 11 (Sustainable Cities and Communities) [51]. Such variation in goal alignment would suggest that the position and role of an organisation within the supply network influences its view of how it can effect change and thus which SDGs are most relevant. This view is supported by Schmidt et al. [67] who note that, whilst stakeholders advocate "monolithic" outcomes across the supply chain, very different issues are salient for different companies, which therefore set different goals depending on their position within the supply network [68]. This highlights the difficulty of aligning goals and targets between different parts of the value network, even where strong relationships already exist.

The Modern Slavery approach demonstrates less well-developed collaboration within the supply network: collaboration may reach beyond the first tier of contractors but lacks the clarity and consistency provided by a Chain of Custody process. This study has confirmed how construction companies, such as Carillion, with strong social and ethical stances will implement policies, undertake audits, and work collaboratively with employees and local groups in an attempt to prevent slavery. However, other stakeholders in the supply system have identified that they have a role to play in supporting Decent work and affordable growth (SDG8) but did not link this with SDG12, the performance of the whole supply network. Unlike FSC, there is currently no "bottom-up" approach; it appears that an "imposed" principle, such as the prevention of modern slavery, is extremely difficult to deliver throughout the supply network. This becomes increasingly problematic where peer organisations, and public bodies are not engaged with the issue. A recent report by Segall and Labowitz [69] concluded that breaking the "cycle of abuse" needs stronger legal enforcement; in particular, much greater regulation of the recruitment process and collaboration between all actors in the supply network is needed, to include countries where migrant workers are recruited.

\section{Operationalising the SDGs-Value Driven Approaches}

Improvements in the sustainability of supply networks are generally limited to incremental improvements; of doing "less bad". Although the SDGs have been presented as a way to enable more radical reductions in unsustainability, they do not challenge the incremental approach and as yet have not offered targets based on operating boundaries. The targets and indicators that do currently exist offer limited guidance on how commercial actions can be effectively aligned with the SDGs or the Planetary Boundaries [37]. Currently the only explicitly "business focused" indicator for SDG12 is Indicator 12.6.1-“Number of companies publishing sustainability reports" [70]—which is focussed on process rather than outcome. Such weakly articulated aspirations do little to discourage the current business focus on "how a company can contribute" rather than "how it will deliver" [71].

Therefore, there is a role for trade associations and commercial organisations to develop sectoral approaches and guidelines, loosely analogous to the Product Category Rules (PCRs) used 
in product labelling and based, like PCRs, on shared goals and aspirations. Some large corporations, who are identified as adopting leading sustainable practises, appear to have the necessary "shared, organisation-wide long-term vision" and exhibit "core values and cultures and a sense of purpose beyond the economic bottom line" [72]. In a traditional view of supply networks this is demonstrated by the "corporation" acting as the driving force for implementing CSR through selective commercial pressures on organisations in its upstream supply network. It operates as a hub for stakeholder engagement, on the implicit assumption that the principles of the corporation have precedence over those of other organisations within the network [23]. This is echoed by Jorgensen and Knudsen [73] who note that larger buyers, acting as change agents, exert pressure on their supplier tiers to comply with their environmental and social requirements. It has been argued $[23,74,75]$ that, as the corporation develops these relationships, it moves beyond an adversarial negotiating stance to one of co-operation as it seeks to propagate its own principles through the supply network. This would appear to be the current position with modern slavery: the corporation, driven by legislation and supported by NGOs, tries to require specific social values to be upheld throughout the supply network.

By contrast, the approach followed by FSC has led to development of a different dynamic in the supply network. Through the creation of the FSC "brand" and rigorous certification structure, forest owners have built an equally strong position in the supply network, with network power being found at both raw material and "retail" ends of the network [76]. Both dominant groups value the importance of their reputation and, in the approach presented, both Carillion and FSC shared a similar set of "values". Both organisations had strong self-interest to co-operate but in doing so were also working towards goals with longer-term benefits, beyond those which both parties originally expected. These included generating wealth for local communities, especially local SMEs, and providing buyers with a high level of confidence in the fair treatment of people working in the supply network.

\section{Conclusions}

The FSC multi-stakeholder approach highlights the practical value of shared goals and principles as the basis for long-term supply network relationships and collaboration. NGO oversight and certification creates transparency and ensures compliance even by actors in the supply network whose commitment to the goals may be weaker. FSC appears to operate most effectively at a sector level rather than just a single supply network: what started as a "bottom-up" approach has developed into a shared position of network "power". Interestingly, whilst aligned goals support a shared vision, the complementarity between the roles of FSC and Carillion in the supply network could ensure the achievement of sustainable outcomes: FSC represents those directly involved in forestry, working to overcome environmental and social issues associated with illegal logging, whilst Carillion could offer the economic driver to deliver change. We argue that this complementarity promotes change towards sustainability but makes alignment with a single unifying SDG unrealistic.

Whilst the SDGs do set "slavery" within the context of wider sustainability goals, they may still be seen as merely rebadging earlier failed agreements: 178 nations are signatories to the ILO Forced Labour Convention of 1930 [77] but this has not eliminated slavery from supply networks. SDGs do not provide a new practical framework for successful delivery of fair labour. Where moves to eliminate modern slavery from the construction sector have been successful, they have exhibited some of the characteristics demonstrated in the FSC Chain of Custody approach; i.e., engagement with peers and NGOs that expands stakeholder collaboration and the creation of a more transparent corporate approach.

Thus, the difference in effectiveness between the two approaches reviewed in this work shows that, without alignment of principles and goals or shared vision throughout all tiers of the supply network, it is hard to motivate actors in the supply network to engage so that progress in reducing unsustainability is limited. Principles and goals are, however, individual, and vary between cultures, industrial sectors, organisations of different sizes, etc. They develop within an organisation through the complex interaction of information, experience and surrounding behaviours. The potential is 
high for divergent and non-complementary behaviours within individual SDGs between different actors in the supply network, resulting from their different values and priorities. Hence, it is possible that the SDGs will struggle to be universally adopted without complementary behaviours within the supply network.

Whilst this research has considered the role of supply networks within the construction sector, we suggest that the scenarios explored will have resonance in other sectors where brand dominance and consumer pressure is limited. The UN Sustainable Development Goals have undoubtedly succeeded in raising awareness amongst a broad range of actors and stakeholders of the issues grouped under the heading of "sustainability", but this research suggests that they may be less successful in providing companies with a practical decision-making framework, especially in the context of complex global supply networks. Much more work is needed to make the Goals operational. The top-down and bottom-up goal-setting approaches examined in this paper reflect two different ways to embed sustainability in an industrial sector. Based on the exploration reported here, we suggest that the bottom-up approach is ultimately more likely to be successful because it promotes alignment of goals and/or principles between the different actors in the supply network, so that all actors can gain benefit from the relationship and have the flexibility to focus on the goals that are most relevant to them. Given the demise of Carillion, after the research reported here, there is no possibility to continue this particular investigation. However, a longitudinal study is really needed to explore and compare the effectiveness of different approaches in embedding more sustainable practices in companies in this and other sectors.

Acknowledgments: Carillion plc was and EPSRC is a funder of the University of Surrey Doctoral Practitioner student Erica Russell. The work of Jacquetta Lee is funded by the University of Surrey. Roland Clift's contribution is unfunded.

Author Contributions: The paper was jointly conceived by all authors through discussion and written communication. The initial framing of the paper was suggested by Roland Clift and the analysis of different approaches has been drawn from PhD thesis material by Erica Russell based on work within Carillion plc. Jacquetta Lee led the results and observations sections with contributions from all authors.

Conflicts of Interest: The authors declare no conflict of interest. Carillion plc played no role in the design, collection, analysis or interpretation of the data. They did read the manuscript prior to submission and noted several factual inaccuracies which were amended.

\section{Appendix A. Semi Structured Orientation Interview Questions}

Note: The original survey included additional prompts for several of the questions based on corporate procedure. Some of these details are confidential and have not been included in this Appendix.

Question to be asked by Interviewer to prompt discussion

1. Please could you outline your role and how this fits within the supply chain (SC) team.

2. How do you select suppliers and monitor supplier performance?

3. What typically is the relationship/communication routes that the SC team have with suppliers?

4. How do you see Carillion's supply chain? (those involved in face to face meetings to be shown the three basic models, Figures A1-A3).

5. How far down the chain do you think Carillion have direct or indirect influence currently?

6. When you report KPIs for Carillion, how far down the chain do you report?

7. What do you think suppliers understand about sustainability? (Does it matter? to whom)

8. When, as part of tendering process, is Sustainability flagged as an important criterion?

9. If you talk to suppliers what do you say are the key sustainability goals that Carillion are looking to achieve through their work.

10. How do you keep up to date with the company's sustainability objectives/goals?

11. If suppliers don't know about sustainability where do you suggest they go if they want help? 
12. Can suppliers respond to requests for more innovative approaches/more sustainable approaches? (prompt: Examples of success)

13. What do you think are the big barriers/issues that need to be turned into opportunities?

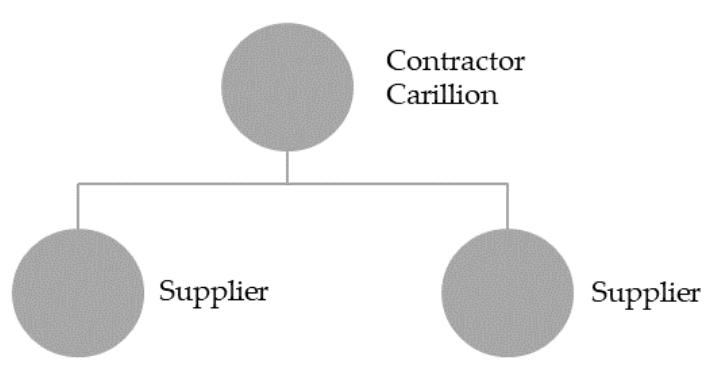

Figure A1. Upstream Tier 1 Supplier Model.

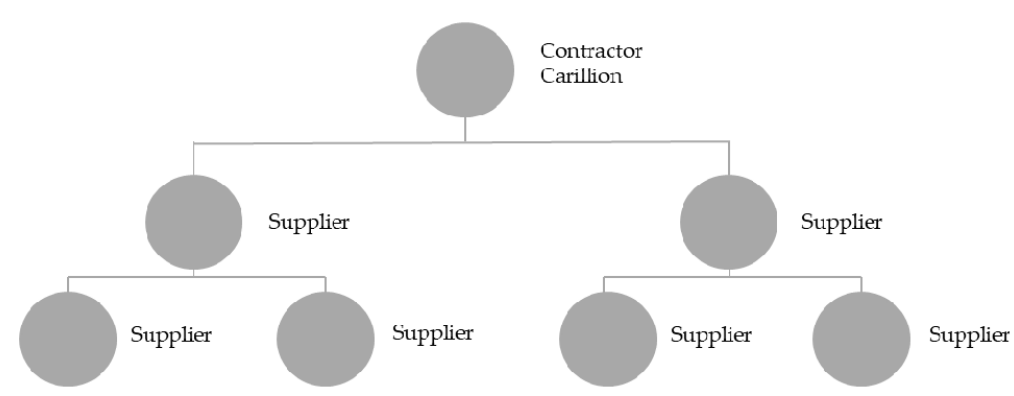

Figure A2. Upstream Multiple Supplier Model.

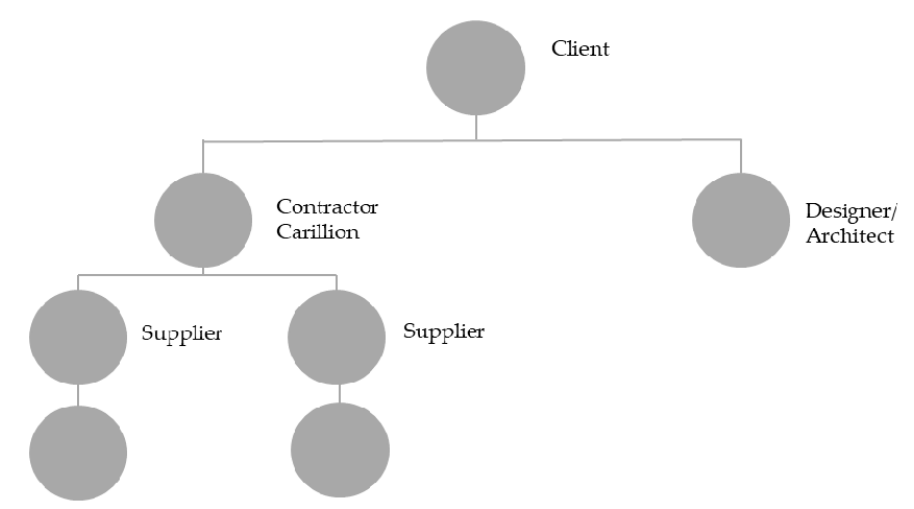

Figure A3. Upstream and Downstream Supply Network Model.

\section{Appendix B. Sustainable Development Goals Supported by FSC}

Table A1. Sustainable Development Goals Supported by FSC.

\begin{tabular}{ll}
\hline SDGs Supported & SDG Targets Supported \\
\hline Primary Goal & $\begin{array}{l}\text { Main Target: } 15.2 \text { By 2020, promote the implementation of sustainable } \\
\text { management of all types of forests, halt deforestation, restore degraded } \\
\text { forests and substantially increase afforestation and reforestation globally }\end{array}$ \\
\cline { 2 - 2 } 15. Life on Land & $\begin{array}{l}\text { Secondary Targets: } \\
\text { 15.1, 15.3, 15.4, 15.5, 15.7, 15.8, 15.c }\end{array}$ \\
\hline
\end{tabular}


Table A1. Cont.

\begin{tabular}{ll}
\hline SDGs Supported & SDG Targets Supported \\
\hline Additional Goals & \\
\hline 1. No Poverty & 1.5 \\
\hline 2. Zero Hunger & 2.4 \\
\hline 5. Gender Equality & $5.5,5 . \mathrm{a}$ \\
\hline 6. Clean water and sanitation & $6.4,6.5,6.6,6.7$ \\
\hline 7. Affordable and clean energy & 7.2 \\
\hline 8. Decent work and economic growth & $8.4,8.5,8.7,8.8$, \\
\hline
\end{tabular}

\section{References}

1. Oxford Economics. Global Construction 2025; Oxford Economics: Oxford, UK, 2013.

2. Independent Police Complaints Council (IPCC). Climate Change 2014: Mitigation of Climate Change. Contribution of Working Group III to the Fifth Assessment Report of the Intergovernmental Panel on Climate Change; Edenhofer, O., Pichs-Madruga, R., Sokona, Y., Farahani, E., Kadner, S., Seyboth, K., Adler, A., Baum, I., Brunner, S., Eickemeier, P., et al., Eds.; Cambridge University Press: Cambridge, UK; New York, NY, USA, 2014.

3. United Nations Environment Programme (UNEP). Buildings and Climate Change: Summary for Decision Makers; United Nations Environmental Programme-Sustainable Buildings and Climate Initiative: Paris, France, 2009.

4. Green, S. The evolution of corporate social responsibility in construction. In Corporate Social Responsibility in the Construction Industry; Taylor and Francis: London, UK, 2008.

5. Cherns, A.; Bryant, D. Studying the client's role in construction management. Constr. Manag. Econ. 1984, 2, 177-184. [CrossRef]

6. Carillion. A Better Tomorrow: Sustainability Report 2015. Wolverhampton: Carillion plc. 2016. Available online: http:/ / sustainability2015.carillionplc.com/assets/files/carillion-sr2015-full.pdf (accessed on 2 February 2017). (Archived by WebCite ${ }^{\circledR}$ at http://www.webcitation.org/6xBZOaUQ0).

7. Scholman, H.S.A. Uitbesteding Door Hoofdaannemers (Subcontracting by Main Contractors); Economisch Instituut Voor de Bouwnijverheid: Amsterdam, The Netherlands, 1997.

8. Korczynski, M. The low-trust route to economic development: Inter-firm relations in the UK engineering construction industry in the 1980s and 1990s. J. Manag. Stud. 1996, 33, 787-808. [CrossRef]

9. Akitoye, A.; Mcintosh, G.; Fitzgerald, E. A survey of supply chain collaboration and management in the UK construction industry. Eur. J. Purch. Supply Manag. 2000, 6, 159-168. [CrossRef]

10. The Economist. Where Did Carillion Go Wrong? Available online: https://www.economist.com/news/ britain/21735047-mistakes-caused-mega-contractors-demise-are-common-outsourcing-industry-where (accessed on 18 January 2018). (Archived by WebCite ${ }^{\circledR}$ at http:/ / www.webcitation.org/6xBXBdihE).

11. King, A.P.; Pitt, M.C. Supply chain management: A main contractors perspective. In Construction Supply Chain Management: Concepts and Case Studies; Pryke, S., Ed.; Wiley-Blackwell: Oxford, UK, 2009; pp. 189-192.

12. Saad, M.; Jones, M.; James, P. A review of the progress towards the adoption of supply chain management (SCM) relationships in construction. Eur. J. Purch. Supply Manag. 2002, 8, 173-183. [CrossRef]

13. Briscoe, G.; Dainty, A. Construction supply chain integration: An elusive goal? Supply Chain Manag. Int. J. 2005, 10, 319-326. [CrossRef]

14. Skitmore, M.; Smyth, H. Marketing and pricing Strategy. In Construction Supply Chain Management Concepts and Case Studies; Pryke, S., Ed.; Wiley Blackwell: Oxford, UK, 2009.

15. Russell, E.F. Investigation into the Use of Main Contractor Category Management to Improve Sustainability within the Construction Supply Network. Ph.D. Thesis, University of Surrey, Guildford, UK, 2017.

16. Bank for International Settlements (BIS). Industrial Strategy: Industry and Government in Partnership: Construction 2025; HMSO: London, UK, 2013. 
17. Fawcett, S.E.; Magnum, G.M. The rhetoric and reality of supply chain integration. Int. J. Phys. Distrib. Logist. Manag. 2002, 32, 339-361. [CrossRef]

18. Vurro, C.; Russo, A.; Perrrini, F. Shaping sustainable value chains: Network determinants of supply chain governance models. J. Bus. Ethics 2009, 90, 607-621. [CrossRef]

19. Fernie, S.; Tennant, S. The non-adoption of supply chain management. Constr. Manag. Econ. 2013, 31, 1038-1058. [CrossRef]

20. Nystrom, J. Partnering: Definition, Theory and Evaluation. Ph.D. Thesis, Royal Institute of Technology (KTH), Stockholm, Sweden, 2007.

21. Brinkhoff, A.; Thonemann, U.W. Perfekte Projekte in der Lieferkette. Harv. Bus. Manag. 2007, 7, 6-9.

22. Clift, R.; Sim, S.; Sinclair, P. Sustainable consumption and production: Quality, luxury and supply chain equity. In Treatise in Sustainability Science and Engineering; Jawahir, I.S., Sikhdar, S., Huang, Y., Eds.; Springer: Heidelberg, Germany, 2013; pp. 291-309.

23. Spence, L.; Bourlakis, M. The evolution from corporate social responsibility to supply chain responsibility: The case of Waitrose. Supply Chain Manag. 2009, 14, 291-302. [CrossRef]

24. Hobbs, G. Construction and Resources Roadmap; BRE Report Prepared for DEFRA's Business Waste and Resource Efficiency Programme (BREW); BRE: Watford, UK, 2008; Available online: https:/ /www.bre.co. uk/filelibrary/pdf/rpts/waste/Roadmap_final.pdf (accessed on 28 December 2017).

25. WRAP. Current Practices and Future Potential in Modern Methods of Construction, Ref WAS003-001. 2007. Available online: http:/ / www.wrap.org.uk/sites/files/wrap/Modern\%20Methods\%20of\%20Construction\% 20Full.pdf (accessed on 24 January 2018). (Archived by WebCite ${ }^{\circledR}$ at http://www.webcitation.org/ 6xBXNwYDo).

26. HM Government. UK Annual Report on Modern Slavery. 2017. Available online: https: / / www.gov.uk/government/uploads/system/uploads/attachment_data/file/652366/2017_uk_ annual_report_on_modern_slavery.pdf (accessed on 27 December 2017). (Archived by WebCite ${ }^{\circledR}$ at http:/ / www.webcitation.org/6xBXZdy7I).

27. Walk Free Foundation. The Global Slavery Index 2016; The Minderoo Foundation Pty Ltd.: Dalkeith, Australia, 2016.

28. ILO. Global Estimates of Modern Slavery: Forced Labour and Marriage. 19 September 2017. Available online: http://www.ilo.org/wcmsp5/groups/public/---dgreports/---dcomm/documents/ publication/wcms_575479.pdf (accessed on 21 January 2017). (Archived by WebCite ${ }^{\circledR}$ at http://www. webcitation.org/6xBXiAzXF).

29. United Nations. Transforming Our World: The 2030 Agenda for Sustainable Development. A/RES/70/1; United Nations: New York, NY, USA, 2015.

30. Jackson, T. Keeping out the giraffes. In Long Horizons; Tickell, A., Ed.; British Council: London, UK, $2010 ;$ p. 20.

31. Globescan. Evaluating Progress towards the Sustainable Development Goals. Globescan/Sustainability Survey; Globescan: Toronto, ON, Canada, 2017.

32. UN. United Nations Sustainable Development Goals, Sustainable Development Agenda. 2015. Available online: http://www.un.org/sustainabledevelopment/development-agenda/ (accessed on 9 January 2018). (Archived by WebCite ${ }^{\circledR}$ at http:/ / www.webcitation.org/6xBXp5g2H).

33. Environmental Audit Committee. Sustainable Development Goals in the UK; House of Commons: London, UK, 2017.

34. Ethical Corp. Sustainability in Europe-Top Trends; Ethical Corporation: London, UK, 2017.

35. Rockström, J.; Steffen, W.; Noone, K.; Persson, A.; Chapin, F.S., III; Lambin, E.F.; Lenton, T.M.; Scheffer, M.; Folke, C.; Schellnhuber, H.J.; et al. A safe operating space for humanity. Nature 2009, 461, 472-475.

36. Steffen, W.; Richardson, K.; Rockström, J.; Cornell, S.E.; Fetzer, I.; Bennett, E.M.; Biggs, R.; Carpenter, S.R.; Vries, W.D.; de Wit, C.A.; et al. Planetary boundaries: Guiding human development on a changing planet. Science 2015, 347. [CrossRef] [PubMed]

37. Clift, R.; Sim, S.; King, H.; Chenoweth, J.L.; Christie, I.; Clavreul, J.; Mueller, C.; Posthuma, L.; Boulay, A.M.; Chaplin-Kramer, R.; et al. The challenges of applying planetary boundaries as a basis for strategic decision-making in companies with global supply chains. Sustainability 2017, 9, 279. [CrossRef]

38. Clift, R. Metrics for Supply Chain Sustainability. Clean Technol. Environ. Policy 2003, 5, 240-247. [CrossRef] 
39. Glasser, B.G.; Strauss, A.L. The Discovery of Grounded Theory: Strategies for Qualitative Research; Aldine Publishing Company: Hawthorne, NY, USA, 2008.

40. Gilbert, N.; Stoneman, P. Researching Social Life, 4th ed.; Sage: London, UK, 2016.

41. Carillion. Sustainability Report 2014: Our Business. Wolverhampton: Carillion plc. 2015. Available online: http:/ / sustainability2014.carillionplc.com/assets/files/carillion-sr2014-full.pdf (accessed on 7 May 2017). (Archived by WebCite ${ }^{\circledR}$ at http:/ / www.webcitation.org/6xBZ8AZCh).

42. Sandelowski, M. Qualitative analysis: What it is and how to begin. Res. Nurs. Health 1995, 18, 371-375. [CrossRef] [PubMed]

43. European Union. Council Regulation (EU) No. 995/2010 Laying down the obligations of operators who place timber and timber products on the market. Off. J. Eur. Union 2010, 53, 23-34. Available online: http:/ / eur-lex.europa.eu/legal-content/EN/TXT/PDF/?uri=OJ:L:2010:295:FULL\&from=EN (accessed on 12 September 2017).

44. Strauss, A. Qualitative Analysis for Social Scientists; Cambridge University Press: Cambridge, UK, 1987.

45. Khan, S.; VanWynsberghe, R. Cultivating the Under-Mined: Cross-Case Analysis as Knowledge Mobilization. Forum Qualitative Sozialforschung/Forum: Qualitative Social Research, [S.1.]. 2008, Volume 9. Available online: http:/ / www.qualitative-research.net/index.php/fqs/article/view/334/729 (accessed on 18 February 2018).

46. Murphy, D.F.; Bendell, J. Do-it yourself or do-it together? The implementation of sustainable timber purchasing policies by DIY retailers in the UK. In Greener Purchasing: Opportunities and Innovations; Russel, T., Ed.; Greenleaf Publishing: Sheffield, UK, 1998; pp. 118-134.

47. FSC. The 10 FSC Principles. 2017. Available online: http://www.fsc-uk.org/en-uk/about-fsc/what-isfsc/fsc-principles (accessed on 3 May 2017). (Archived by WebCite ${ }^{\circledR}$ at http:/ / www.webcitation.org/ 6xBXwVgke).

48. Breukink, G.; Levin, J.; Mo, K. Profitability and Sustainability in Responsible Forestry: Economic Impacts of FSC Certification on Forest Operators, WWF. 2015. Available online: http:/ / d2ouvy59p0dg6k.cloudfront. net/downloads/profitability_and_sustainability_in_responsible_forestry_main_report_final.pdf (accessed on 13 September 2017).

49. Carillion. We Are Making Choices: Carillion's Environment, Community and Social Report 1999-2000; Carillion plc: Wolverhampton, UK, 2000.

50. GFTN. GFTN-UK Forest Product Reporting Summary for 2015: Carillion plc. 2016. Available online: https: / / carillionplc-uploads-shared.s3-eu-west-1.amazonaws.com/wp-content/uploads/2016/08/ 1332BJ-carillion-gftn-uk-2015-published-timber-report-original.pdf (accessed on 3 May 2017). (Archived by WebCite ${ }^{\circledR}$ at http:/ / www.webcitation.org/6xBY8pzrJ).

51. Carillion. How We're Making Tomorrow a Better Place: Carillion Sustainability Report 2016. Wolverhampton: Carillion plc. 2017. Available online: http://sustainability2016.carillionplc.com/assets/files/carillionsr2016-full.pdf (accessed on 6 June 2017). (Archived by WebCite ${ }^{\circledR}$ at http://www.webcitation.org/ 6xBaRFVYP).

52. Carillion. Supply Chain Team Survey; Carillion: Wolverhampton, UK, 2017; unpublish.

53. UK Government. UK Modern Slavery Act. 2015. Available online: http://www.legislation.gov.uk/ukpga/ 2015/30/contents/enacted (accessed on 3 May 2017). (Archived by WebCite ${ }^{\circledR}$ at http:/ / www.webcitation. org /6xBYqVD4m).

54. Silverman, B. Modern Slavery: An application of Multiple Systems Estimation, UK Government, London. 2014. Available online: https:/ / www.gov.uk/government/uploads/system/uploads/attachment_data/ file/386841/Modern_Slavery_an_application_of_MSE_revised.pdf (accessed on 3 May 2017). (Archived by WebCite ${ }^{\circledR}$ at http:/ /www.webcitation.org/6xBYHOaez).

55. United Nations Environment Programme (UNEP). Greening the Building Supply Chain. United Nations Environment Programme. In Division of Technology, Industry and Economics; Sustainable Buildings and Climate Initiative: Paris, France, 2014.

56. Allain, J.; Crane, A.; LeBaron, G.; Behbahani, L. Forced Labour's Business Models and Supply Chains; Joseph Rowntree Foundation \& Queens University: Belfast, UK, 2013. 
57. Gold, S.; Trautrims, A.; Trodd, Z. Modern slavery challenges to supply chain management. Supply Chain Manag. Int. J. 2015, 20, 485-494. [CrossRef]

58. New, S. Modern slavery and the supply chain: The limits of corporate social responsibility? Supply Chain Manag. Int. J. 2015, 20, 697-707. [CrossRef]

59. Carillion. Labour Standards Charter. 2017. Available online: https://carillionplc-uploadsshared.s3-eu-west-1.amazonaws.com/wp-content/uploads/2017/01/0919FQ-cai0209_labourstandards-charter_jan2017-original.pdf (accessed on 5 May 2017). (Archived by WebCite ${ }^{\circledR}$ at http:/ / www.webcitation.org/6xBYgCHY9).

60. Action Sustainability, Supply Chain Sustainability School: Modern Slavery. 2016. Available online: https: / / www.supplychainschool.co.uk/default/modern-slavery.aspx (accessed on 7 May 2017). (Archived by WebCite ${ }^{\circledR}$ at http://www.webcitation.org/6xBYQAJ3f).

61. Lloyd-Roberts, S. Qatar 2022: Construction Firms Accused Amid Building Boom, BBC Newsnight. 8 December 2014. Available online: http://www.bbc.co.uk/news/business-30295183 (accessed on 9 November 2017). (Archived by WebCite ${ }^{\circledR}$ at http:/ / www.webcitation.org/6xBamEK3H).

62. Basset Hound Rescue Southern California (BHRSC). A Wall of Silence: The Construction Sector's Response to Migrant Rights in Qatar and UEA; Business and Human Rights Resource Centre: London, UK, 2016.

63. Booth, R.; Kelly, A. Migrant Workers in Qatar Still at Risk Despite Reforms, Warns Amnesty, The Guardian. 13 December 2016. Available online: https:/ /www.theguardian.com/global-development/2016/dec/13/ migrant-workers-in-qatar-still-at-risk-despite-reforms-warns-amnesty (accessed on 9 November 2017). (Archived by WebCite ${ }^{\circledR}$ at http:/ /www.webcitation.org/6xBaeDovb).

64. Cai, X.; Tsai, C.; Wu, W. Are they neck and neck in the affordable housing policies? A cross case comparison of three metropolitan cities in China. Sustainability 2017, 9, 542. [CrossRef]

65. Oelze, N. Sustainable supply chain management implementation-Enablers and barriers in the textile industry. Sustainability 2017, 9, 1435. [CrossRef]

66. FSC. FSC ${ }^{\circledR}$ : A Tool to Implement the Sustainable Development Goals. 2016. Available online: https: / / ic.fsc.org/en/web-page- / fsc-contributions-to-achieving-the-sustainable-development-goals (accessed on 6 May 2017). (Archived by WebCite ${ }^{\circledR}$ at http:/ / www.webcitation.org/6xBazluYG).

67. Schmidt, C.; Foerstl, K.; Schaltenbrand, B. The supply chain position paradox: Green practices and firm performance. J. Supply Chain Manag. 2017, 53, 3-25. [CrossRef]

68. Gualandris, J.; Klassen, R.D.; S Vachon, S.; Kalchschmidt, M. Sustainable evaluation and verification in supply chains: Aligning and leveraging accountability to stakeholders. J. Oper. Manag. 2015, 38, 1-13. [CrossRef]

69. Segall, D.; Labowitz, S. Making Workers Pay: Recruitment of the Migrant Labor Force in the Gulf Construction Industry; NYU Stern Centre for Business and Human Rights: New York, NY, USA, 2017.

70. UNSD. Global Indicator Framework for the Sustainable Development Goals and Targets of the 2030 Agenda for Sustainable Development, Global Indicator Framework A RES 71313 Annex, Statistical Commission Pertaining to the 2030 Agenda for Sustainable Development. United Nations, 2017. Available online: https://unstats.un.org/sdgs/indicators/Global\%20Indicator\%20Framework_A.RES.71. 313\%20Annex.pdf (accessed on 8 November 2017). (Archived by WebCite ${ }^{\circledR}$ at http:/ / www.webcitation.org/ 6xBbEFjMi).

71. University of Cambridge Institute for Sustainability Leadership (CISL). Towards a Sustainable Economy: The Commercial Imperative for Business to Deliver the UN Sustainable Development Goals; Vrettos, A., Ed.; CISL; University of Cambridge: Cambridge, UK, 2017; p. 5.

72. Carter, C.R.; Rogers, D.S. A framework of sustainable supply chain management: Moving toward new theory. Int. J. Phys. Distrib. Logist. Manag. 2008, 38, 360-387. [CrossRef]

73. Jorgensesn, A.L.; Knudsen, J.S. Sustainable competitiveness in global value chains: How do small Danish firms behave. Corp. Gov. Int. J. Bus. Soc. 2006, 6, 449-462. [CrossRef]

74. Spekman, R.; Kamauff, J.; Myhr, N. An empirical investigation into supply chain management: A perspective on partnerships. Int. J. Phys. Distrib. Logist. Manag. 1998, 34, 414-433. [CrossRef]

75. Duffy, R.; Fearne, A. Partnerships and alliances in UK supermarket supply networks. In Food Supply Cain Management; Bourlakis, M., Weightman, P., Eds.; Blackwell: Oxford, UK, 2004; pp. 136-152. 
76. Roberts, S. Supply Chain Specific? Understanding the Patchy Success of Ethical Sourcing Initiatives. J. Bus. Ethics 2003, 44, 159-170. [CrossRef]

77. ILO Forced Labour Convention (No29), Geneva, Switzerland, 1930. Available online: http://www. ilo.org/wcmsp5/groups/public/@asia/@robangkok/documents/genericdocument/wcms_346435.pdf (accessed on 28 December 2017). (Archived by WebCite®at http:/ / www.webcitation.org/6xBYYUDum). 